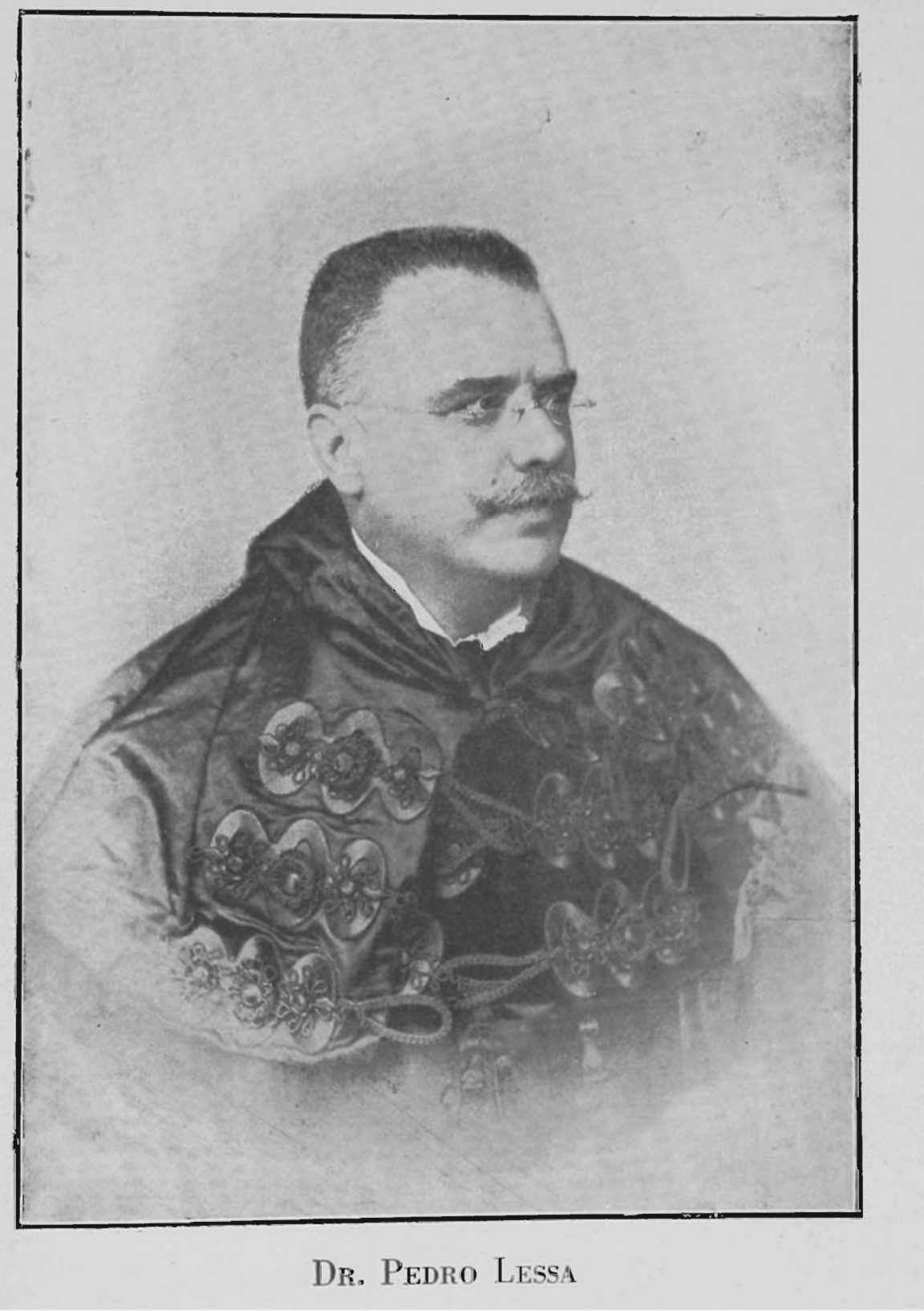




\section{MINISTR0 PEDR0 LESSA}

Limitar-se-á a Redacção da Revista da Faculdade a dar os traços biographicos do grande Juiz, justamente appellidado o Marshall brasileiro. Sobre seu valor, sobre seus trabalhos, já muito se publicou pela imprensa, já muito se disse nas sociedades scientificas. A Revista do Supremo Tribunal, em seu vol. 30 deu uma longa noticia das manifestações de pezar pelo fallecimento do grande Mestre, intemerato Juiz e esforçado patriota. Nasceu na cidade do Serro, Estado de Minas Geraes, a 25 de Setembro de 1859. Era filho do Coronel José Pedro Lessa e de D. Francisca Amelia Carneiro. Fez seus estudos em Vassouras, Estado do Rio de Janeiro. Formado em 1883, logo depois foi nomeado Secretario do Tribunal da Relação de São Paulo. Inscreveu-se em dois concursos, tendo sido nomeado no $2 .^{\circ}$ em que entrou em 1888. Ensinou durante 20 annos em nossa Faculdade. Quando estudante, redigiu o Republica, e o Federalista, que fundára com Alberto Salles e Alcides Lima. Foi em 1907 nomeado Ministro do Supremo Tribunal Federal. Falleceu a 25 de Julho de 1921. Foi o fundador da associação "Liga da Defesa Nacional" Deixou muitas obras, dentre as quaes se destacam a "Philosophia do Direito" e "Do Poder Judiciario" 